\title{
INOVASI KOMUNIKASI PEMASARAN PADA RRI SEMARANG
}

\author{
Agus Triyono \\ Program Studi Penyiaran, Fakultas Ilmu Komputer \\ Universitas Dian Nuswantoro \\ Jl. Nakula I No.5-11 Semarang \\ Telp(024)3517261, Fax (024) 3520165 \\ Email; agustriyono7@gmail.com \\ Mobile; 081325214996
}

\begin{abstract}
Abstrak
Keberadaan RRI Semarang sebagai salah satu media massa elektronik memiliki peran penting dalam menyampaikan informasi kepada publik. Sebagai radio publik, RRI Semarang dituntut untuk tetap eksis dan bersaing dengan banyaknya stasiun radio yang ada. Penelitian ini bertujuan untuk mengetahui banyak hal yang terkait dengan inovasi yang dilakukan RRI Semarang dalam mempertahankan eksistensinya. Penelitian ini menggunakan metode kualitatif deskriptif dengan mendeskripsikan hasil temuan di lapangan. Hasil penelitian menunjukkan, RRI Semarang banyak melakukan inovasi baik on air dan off air yang mampu menyesuaikan kondisi masyarakat di Semarang dan sekitarnya.
\end{abstract}

Kata kunci : inovasi, komunikasi pemasaran, pendengar

\begin{abstract}
The existence of the RRI Semarang electronic mass media has an important role in conveying information to the public. For public radio, RRI Semarang required to exist and compete with many existing radio station. This study aims to determine a lot of things related to the innovations RRI Semarang in maintaining its existence. This research uses descriptive qualitative method to describe the findings in the field. The results showed, RRI Semarang many innovations through activities on air and off air that is able to adjust the conditions in Semarang and surrounding communities.
\end{abstract}

Keyword ; inovasi, marketing communications, audience

\section{Pendahuluan}

Radio merupakan salah satu media massa elektronik berfungsi memberikan informasi, pengetahuan, dan hiburan. Radio mempunyai ciri dan sifat yang berbeda dengan media massa lainnya. Berbeda dengan surat kabar yang merupakan media cetak, juga dengan film yang berorientasi audio dan video yang mengedepankan gambar dan suara dan bersifat yang mekanik optik.

Begitu banyak media massa yang berkembang pesat hingga saat ini, tak terkecuali sebuah stasiun radio yang terus update atas program yang disiarkan. Para pendengar atau audience, dewasa ini sudah sangat cerdas dalam memilih stasiun radio sesuai dengan kebutuhannya. Banyak stasiun radio berupaya memberikan program acara sesuai dengan keinginan pendengar. Oleh karenanya setiap pesan yang ingin disampaikan harus dikemas menarik supaya dapat memikat pendengarnya. Program-program yang diproduksikan 
harus disesuaikan dengan keinginan pendengar supaya mereka tetap setia untuk mendengarkan radio. Apalagi dengan semakin menjamurnya media-media lain yang juga menawarkan program yang menarik yang akan menambah referensi masyarakat dalam mengkonsumsi media yang akan mereka pilih. Hal ini tentunya menjadi tantangan tersendiri untuk sebuah radio siaran. Tak terkecuali Radio RRI Semarang berupaya melakukan terobosan dengan kegiatan on air dan off air yang dilakukannya untuk menarik simpati bagi pendengarnya. Sebagai stasiun radio yang notabene milik pemerintah, radio ini juga melakukan kreatifitas untuk bersaing dengan radio-radio lainnya.

Seperti dilakukan penelitian terdahulu oleh Naiza Rosalia, dengan judul Faktor-faktor Daya Tarik Stasiun Radio dimana meneliti sebuah stasiun radio swasta di Semarang yakni Hot FM yang merupakan radio baru di Semarang. Hasil penelitian tersebut menunjukkan 4 faktor yang menjadi daya tarik stasiun radio. Yakni, pertama; program siaran, dimana terdiri dari kualitas pemancar,musik, program dan games. Kedua, materi siaran, dimana terdiri dari penyiar, posisi brand, berita dan facebook. Ketiga, audio invorentment yang terdiri dari efek suara dan feature. Keempat, Brand Activation yang terdiri dari hal-hal yang mendukung kegiatan on air yakni keberadaan radio streaming, dan sebagian off air. Rumusan masalah dalam penelitian ini adalah bagaimana inovasi yang dilakukan RRI Semarang sebagai radio layanan publik melayani masyarakat ditengah munculnya stasiun radio lain makin eksis. Stasiun radio ini juga dituntut untuk mampu bertahan dalam menghadapi ketatnya persaingan dengan radio-radio yang ada dan juga harus mampu melakukan inovasi agar program-programnya dapat selalu eksis dan diterima oleh pendengar yang ada.

Tujuan dan manfaat dari penelitian ini adalah untuk mengetahui inovasi yang dilakukan RRI Semarang dalam mempertahankan dan meningkatkan eksistensi di mata publik. Disamping itu juga, untuk mengetahui inovasi-inovasi yang dilakukan baik secara on air maupun off air.

Penelitian menggunakan teori pemasaran sosial menurut Kotler dalam Buchari (2009), yakni suatu desain (rancangan), pelaksanaan dan kontrol dari suatu program-program yang bertujuan untuk meningkatkan penerimaan dari satu ide-ide sosial/akibat-akibat sosial dari satu target grup/sasaran. Pemasaran sosial menggunakan konsep:

- Segmen pasar

- Riset konsumen

- Komunikasi

- Fasilitas

- Insentif

- Pengembangan Konsep

Radio sebagai salah satu lembaga publik, disamping mempunyai kewajiban menginformasikan informasi yang sangat penting bagi masyarakat luas. Namun demikian, keberadaan lembaga ini juga harus berorientasi bagaimana memahami pasar, sehingga eksistensinya terus mendapat hati pendengarnya. Stasiun radio RRI Semarang, harus mempunyai strategi dalam menjalankan kegiatannya. Menurut Sudarmawan (2007) Strategi pemasaran meliputi analisa pasar, perencanaan strategi, pengorganisasian sumber daya dan penyusunan program, pelaksanaan pemasaran, pengendalian terhadap program pemasaran, dan evaluasi. Semuanya harus dijalankan dengan baik karena selain harus bisa mengiklankan dirinya sendiri, radio merupakan media komunikasi pemasaran bagi perusahaan lainnya.

\section{Metode Penelitian}

Bentuk penelitian yang digunakan dalam penelitian ini adalah kualitatif deskriptif yang mengarah pada pendeskripsian secara rinci dan mendalam. Adapun jenis penelitian ini 
adalah penelitian dasar, yaitu sebuah penelitian yang berusaha mengungkap, menggambarkan dan menjelaskan sebuah fenomena tanpa berusaha evaluasi terhadap fenomena tersebut,(Sutopo,2010). Studi yang digunakan dalam penelitian ini adalah studi kasus pada radio publik RRI Semarang.

Penelitian ini menggunakan dua metode teknik pengumpulan data, yaitu wawancara dalam mencatat dokumen/penelaahan terhadap dokumen-dokumen.

(1) Wawancara mendalam yang dilakukan dalam penelitian ini adalah dengan cara berdialog secara langsung dengan berfokus pada hal tertentu. Teknik wawancara ini dilakukan pada semua informan yang meliputi (a) Kepala stasiun radio RRI Semarang (b) devisi marketing radio RRI Semarang, (c) devisi produksi RRI Semarang, (d) pendengar (audience)

Jenis penelitian ini lebih mengarah pada jenis cuplikan yang dikenal dengan Purposive Sampling. Jenis ini memiliki kecenderungan peneliti untuk memilih informan yang dianggap mengetahui informasi akan suatu masalah yang mendalam dan dapat dipercaya untuk menjadi sumber data. Kemudian teknik Purposive sampling dilanjutkan dengan teknik snowball sampling. Teknik pengambilan sampel ini mengimplikasikan jumlah sampel yang semakin membesar seiring dengan perjalanan waktu pengamatan (Pawito,2008)

2) Mencatat dokumen, dilakukan untuk mengumpulkan data pendukung yang dapat memperjelas data utama yang bersumber dari dokumen resmi dan arsip yang terdapat di RRI Semarang. Data tersebut antara lain adalah data program komunikasi pemasaran yang dilakukan pada tahun 2012.

Disini peneliti mengumpulkan data dan informasi yang terkait dengan permasalahan dan dapat dikembangkan dengan informan lainnya sebagai kelengkapan informasi yang diperlukan. Peneliti cenderung memilih informan yang dianggap mengetahui informasi dan masalahnya secara mendalam dan dapat dipercaya. Mereka adalah Kepala Lembaga Penyiaran Publik (LPP RRI Semarang); Dra Hj Saraswati SA, Kepala Seksi Pengembangan Usaha ;Atiks Hindari,SH, Pendengar ; R.Suyarto Sumardiyo Atmojo, Sugiyarto, dan Yuni Ekowatini.

Proses analisis yang digunakan yakni dengan menggunakan model analisis interaktif. model analisis interaktif ini ada ada 3 komponen analisis yakni reduksi data, sajian data dan penarikan simpulan/verifikasinya, aktifitasnya dilakukan dalam bentuk interaktif dengan proses pengumpulan data sebagai suatu proses siklus.(Hadari,2010)

\section{Pembahasan}

Komunikasi Pemasaran di Lembaga Penyiaran Publik RRI dilakukan di seksi Pengembangan Usaha, yang merupakan bagian dari unit yang ada di Radio Republik Indonesia Semarang ini. Devisi Pengembangan Usaha ini meliputi bagian Pencitraan, Layanan Publik dan Pengembangan Usaha. Devisi ini merupakan jembatan bagi RRI khususnya Semarang dalam melakukan komunikasi pemasaran secara sosial. Pentingnya bauran komunikasi pemasaran yang dilakukan oleh sebuah radio pemerintah mempunyai peranan penting dalam membantu kinerja sebagai sebuah stasiun radio publik.

Pemasaran sosial yang dilakukan dengan menggunakan strategi, yang di dalamnya terdapat unsur-unsur seperti analisa pasar, perencanaan strategi, pengorganisasian sumber daya dan penyusunan program, pelaksanaan pemasaran, pengendalian terhadap program pemasaran, dan evaluasi.

\section{Analisa Pasar}

Mengidentifikasi peluang jangka panjang potensial berdasarkan pengalaman pasar dan kompetensi intinya melalui suatu riset pemasaran dan sistem informasi pemasaran yang 
handal. Riset tersebut meliputi lingkungan makro (faktor demografis, ekonomi, fisik, teknologi, politik hukum, dan sosial budaya).Sedangkan lingkungan mikro terdiri dari semua pihak yang mempengaruhi kemampuan perusahaan untuk memproduksi dan menjual produk, perantara pemasaran, pelanggan dan pesaing. Analisa peluang pemasaran disini dimaksudkan untuk mengenali pasar dan mencari pasar yang masih bisa digarap oleh sebuah media penyiaran. Analisa yang biasanya digunakan adalah analisa SWOT (strength, weakness, opportunity, threat). Analisis kekuatan dan kelemahan berfokus pada faktor-faktor internal, sedangkan analisis kesempatan dan ancaman berfokus pada faktor-faktor yang bersifat eksternal. Analisa peluang pasar bagi sebuah radio menjadi hal yang sangat penting mengingat semakin ketatnya persaingan pasar yang semakin kompetitif. Dengan melakukan analisa pasar, sebuah radio akan mengetahui target pasar yang masih bisa dibidik. Setelah diketahui tentang peluang pasar yang ada barulah siap untuk memilih pasar sasaran. Hal yang harus diperhatikan adalah gerakan para pesaing dan mengetahui reaksi mereka baru kemudian menentukan sebuah bauran pemasaran bagi pasar sasaran yang dikejar perusahaan. Pasar yang dipilih tentunya harus sesuai dengan segmentasi radio. Setelah diketahui barulah menentukan strategi-strategi pemasaran yang sesuai. Yang perlu diperhatikan adalah radio lain yang memiliki segmentasi sama.

- Strength atau kekuatan dari RRI Semarang adalah adanya dukungan dari pemerintah pusat dalam penyelenggaraan manajemen RRI Semarang. Dalam operasionalisasinya RRI Semarang masih mempertahankan program siaran yang selama ini menjadi unggulan seperti program diskusi interaktif, program budaya (wayang kulit, wayang orang, budaya-budaya local dan kedaerahan) yang mampu memberikan warna tersendiri bagi masyarakat Semarang dan Jawa Tengah.

- Weakness atau kelemahan. RRI Semarang dikenal masyarakat sebagai radio public milik pemerintah yang stagnan, tidak banyak memberikan kreatifitas sesuai dengan perkembangan jaman masa kini. Ini menjadi kelemahan atas image yang terbangun selama ini. Oleh karenanya RRI Semarang dituntut untuk selalu mengikuti berbagai kemajuan dan perubahan yang terjadi dari waktu ke waktu.

- Opportunity atau kesesempatan. Aspek ini memberikan peluang yang sangat besar bahwa RRI Semarang juga bisa berinovasi yang dilakukan secara on air maupun off air. Secara on air, dalam rangka penyajian program yang menarik sesuai dengan segmentasi dari program pro 1-4 menumbuhkan motivasi yang kuat dalam menciptakan program yang disukai masyarakat. Sementara kegiatan off air, banyak melakukan even-even seperti sepeda sehat, donor darah, kontes wayang kulit, music dan lainnya ikut menambah keberadaan RRI Semarang.

- Treatment atau ancaman. Munculnya berbagai stasiun radio swasta yang selalu berlomba-lomba berinovasi, menuntut RRI Semarang berbenah diri, berkarya dengan melakukan terobosan-terobosan yang dapat menarik perhatian para pendengar.

2. Perencanaan Strategi

Setiap perusahaan mempunyai sasaran-sasaran yang ingin dicapai. Strategi digunakan untuk mencapai sasaran-sasaran tersebut supaya sesuai dengan tujuan yang ingin dicapai.

RRI Semarang menggali potensi yang dimilikinya dengan menyesuaikan kebutuhan masyarakat akan produk siarannya. Mengangkat potensi lokal kedaerahan yang diangkat menjadi sebuah tema atau topic dalam beberapa program siarannya menjadi salah satu strategi yang dibangun untuk mempertahankan eksistensi RRI Semarang. Selain itu, melibatkan tokoh-tokoh yang berpengaruh, public figure untuk ikut serta mengkritisi dan mendorong kebijakan pemerintah daerah dalam meningkatkan informasi dan komunikasi menjadi bagian dari strategi yang digunakan. Langkah ini 
menjadi modal bagi RRI Semarang dalam melakukan survey atau riset pasar sehingga memiliki pasar yang dapat diidentifikasi dengan baik.

3. Pengorganisasian Sumber daya dan penyusunan program. Aspek ini memberikan kesempatan kepada sumber daya yang ada untuk mampu melakukan komunikasi efektif dan kreatifitas sesuai dengan bidangnya masing-masing. Keterlibatan mereka dalam sebuah timwork yang kuat sangat memberikan kontribusi dalam memainkan peran sebagai radio public. SDM di RRI Semarang terdiri dari tim yang terkait dengan manajemen dan produksi siaran. Peran komunikasi dalam unit ini sangat dominan, sehingga mampu mengoptimalkan unit-unit terkait lainnya.

4. Pelaksanaan pemasaran.

Pemasaran di RRI Semarang dilakukan oleh sebuah devisi yang sebut sebagai Pengembangan Usaha. Devisi ini melakukan kegiatan pemasaran baik secara on air maupun off air dimana didukung dengan fasilitas yang cukup untuk memberikan hasil yang diharapkan. Devisi inilah yang membuat kreatifitas dalam rangka peningkatan kegiatan pemasaran untuk meningkatkan kualitas RRI Semarang. Pemasaran disesuaikan dengan kebutuhan radio yang merupakan radio public.

5. Pengendalian terhadap program pemasaran, dilakukan oleh seksi pengembangan usaha. Pengembangan dilakukan dalam lingkungan kreatifitas siaran melalui produksiproduksi yang kreatif, siaran-siaran yang menyesuaikan kebutuhan para pendengar dan disesuaikan dengan segmentasi dari RRI pro $1-4$. Sementara itu, pengendalian secara manajerial dilakukan oleh seorang kepala stasiun RRI Semarang, yang memantau baik secara langsung maupun melalui unit-unit yang ada dibawahnya. Pengendalian ini sangat erat kaitannya dengan reward maupun punishment yang diberikan pada sumber daya yang ada. Bagi yang berprestasi akan mendapatkan insentif yang sesuai dengan hasil kerjanya, dan disesuaikan dengan regulasi yang ada. Sementara, bagi yang prestasinya kurang akan disesuaikan dengan situasi dan kondisi manajemen RRI Semarang.

6. Evaluasi.

Setiap periode tertentu RRI Semarang melakukan evaluasi atas kinerja yang dilakukan oleh unit-unit terkait. Untuk kegiatan pemasaran off air, dilakukan evaluasi dalam jangka panjang, jangka menengah dan jangka pendek. Jangka panjang dilakukan setiap tahun, jangka menengah dilakukan setiap 6 bulan dan 3 bulan. Sementara, jangka pendek dilakukan setiap minggu dan bulanan. Evaluasi ini akan menjadi refleksi atas program kerja yang telah dilakukan selama ini. Jika program yang hasilnya baik akan tetap dipertahankan dan ditingkatkan. Sementara yang kurang baik akan ditinjau kembali untuk pengembangan konsep berikutnya, sehingga kedepan dapat menghasilkan sebuah konsep yang cocok bagi perkembangan RRI Semarang.

Dalam penelitian ini, penulis melakukan wawancara mendalam dengan Kepala Lembaga Penyiaran Publik (LPP)RRI Semarang, Kepala Seksi Pengembangan Usaha, dan pendengar atau audience.

\section{Informan I : Kepala LPP RRI Semarang (Dra Hj Saraswati SA)}

RRI Semarang memasuki usia ke 67 pada tanggal 11 September 2012 lalu. Lembaga ini menjadi sebuah media komunikasi dan informasi bagi masyarakat luas. Moment ini sebagai bentuk aktualisasi diri sekaligus menambah semangat serta nuansa baru bagi kemajuan dunia penyiaran. Hal ini menjadi bentuk niat yang ikhlas dalam memajukan sumber daya manusia dalam mendukung pembangunan. Ia mengaku, kondisi ini sesuai dengan ikrar Tri Prasetya menjadi salah satu kekuatan dalam membangun kondusifitas serta kehidupan kemasyarakatan yang aman dan sejahtera. Informan mengaku, RRI Semarang sebagai lembaga penyiaran publik memiliki tanggung jawab yang besar dan berbeda dengan radio-radio swasta yang 
besifat lebih komersil. Pihaknya mengaku, tetap berupaya meningkatkan kualitas dan mengedepankan sebagai radio yang beorientasi sebagai radio publik, sehingga pemasaran yang dilakukanpun juga berdasar pada layanan publik. Dan,ikut serta mendukung program pembangunan melalui kebijakan pemerintah pusat dan daerah.

\section{Informan II (Atik Hindari,SH ; Kepala Seksi Pengembangan Usaha)}

Temuan dalam wawancara yang dilakukan di stasiun radio RRI ini menemukan temuan yang sangat signifikan. Devisi Pengembangan Usaha memiliki 3 unit atau bagian dalam operasionalisasinya. Pertama adalah Pencitraan, kedua Layanan Publik dan ketiga adalah Pengembangan Usaha. Bidang pengembangan usaha di RRI Semarang sesuai dengan regulasi yang ada, telah banyak melakukan terobosan dan inovasi dalam pengembangan usaha. Usaha yang dilakukan baik internal maupun eksternal. Secara internal ; dengan memperkuat tim yang ada dalam devisi ini yakni ada 4 orang. Meski tergolong kecil, namun tim ini dibekali kemampuan softskill maupun hardskill dalam meningkatkan kompetensinya. Tim ini telah banyak mengikuti training dan pelatihan dibidang penyiaran, komunikasi pemasaran, dan bidang-bidang marketing lainnya yang mendukung devisi ini. Selain itu, tim ini bersama programer radio membuat inovasi dengan mengembangkan,menyiapkan program-program acara yang banyak diminati pendengar. Inovasi ini terbagi dalam 2 aspek yakni internal dan eksternal.

Aspek internal, dengan melakukan inovasi dengan meningkatkan acara yang sudah ada namun dengan modifikasi baru dan pembuatan program acara yang lagi trend.

Program ini dipilah dengan 2 versi yakni program yang kemas khusus dan umum. Khusus dikategorikan memiliki prime time yang sangat spesifik dengan harga khusus. Sementara, program yang umum dikategorikan harga sesuai dengan tarif regular. Beberapa perusahaan baik swasta, BUMN maupun pemerintahan sering kali menggunakan jasa ini. Perusahaan BUMN seperti Askes, PT Pertamina, PT KAI dan beberapa BUMN lainnya.

Selain itu, terdapat temuan lain yang memberikan kontribusi signifikan yakni program yang berkaitan dengan budaya-budaya lokal. Program ini dikemas dalam bentuk feature dan juga layanan seperti halnya profile. Program ini juga mendapat respon positif dari mereka. Aspek Eksternal- Kreatifitas RRI Semarang dalam bidang off air juga mempunyai record yang cukup signifikan. Diantaranya, RRI Semarang ini mampu membuat sebuah EO (Even Organizer) yang menjalankan aktifitas mereka di dunia luar. Lomba jalan sehat, sepeda santai, lomba bintang radio, pentas seni dan kegiatan lainnya yang melibatkan massa dengan intensitas cukup besar mampu menyedot perhatian massa. Even ini, sangat efektif karena banyak sponsor yang ingin melibatkan diri dan berkontribusi dalam even yang diselenggarakan. Meski diakui sponsor yang terlibat lebih banyak dalam rangka meningkatkan citra dan reputasi sebagai radio publik.

\section{Unit Layanan Masyarakat}

Devisi ini berorientasi pada bagaimana memberikan pelayanan yang optimal terkait dengan informasi, pendidikan dan hiburan kepada semua lapisan masyarakat di seluruh Indonesia. Informasi dimaksudkan adalah memberikan informasi sejelas-jelasnya pada masyarakat luas pada beberapa bidang yang dibutuhkan. Penyampaian informasi ini diharapkan mampu memberi kontribusi yang sangat besar dalam menciptakan masyarakat yang melek terhadap informasi. Disamping itu, RRI Semarang sesuai dengan hasil penelitian juga berorientasi dalam bidang pendidikan. Artinya, ikut serta melakukan proses mencerdaskan bangsa melalui siaran-siaran yang mendidik dengan mengedepankan ilmu pengetahuan.

\section{Unit Pencitraan}

Devisi ini merupakan bagian yang juga sangat penting dalam meningkatkan citra maupun image positif masyarakat. Keberadaan unit ini juga menjadi bagian yang tidak terpisahkan 
dari kegiatan RRI Semarang dalam meningkatkan eksistensinya. Sesuai hasil di lapangan RRI Semarang melalui unit ini telah banyak melakukan kegiatan dari aspek sosial, ekonomi, budaya dan politik dalam menunjang kegiatah pencitraan.

\section{Informan III ((R.Suyarto Sumardiyo Atmojo ( 68th)}

Sebagai pendengar setia, Yarto telah mengikuti perkembangan radio sejak tahun 1955. Kesetiaannya dimulai pada masa orde lama pada saat frekuensi radio masih SW hingga kini sudah pada frekuensi FM. Ia sangat eksis dalam mengkritisi siaran dan program di RRI Semarang, terutama yang berkaitan dengan kebijakan publik. Dalam pengakuannya saat diwawancarai peneliti, pak Yarto mengaku sangat memberi apresiasi pada RRI Semarang. Eksistensi RRI sejauh ini terus mengalami perubahan dan peningkatan berarti. Ia berharap, RRI mampu membentuk karakter sendiri dengan meningkatkan perfomanya baik dari sisi konten siaran maupun kegiatan off air. Sebagai radio publik, tidak ada salahnya jika RRI mampu membuat terobosan baru dengan menggali potensi yang ada lebih mendalam dengan mendepankan profesionalitas. RRI juga telah membawa perubahan dengan memberi ruang pada publik atas kebijakan dari para pengambil keputusan di lingkungan Semarang dan Jawa Tengah khususnya dan Indonesia pada umumnya. Hal ini menjadi preseden yang sangat baik, atas konsistensi RRI Semarang dalam keterlibatannya mendukung perubahan peradaban masyarakat menjadi lebih baik.

Ia berharap, RRI mampu lebih kreatif, meski sebagai radio public tetapi dapat berkreasi dengan menyuguhkan inovasi dan karya-karya yang up to date sehingga dapat diterima masyarakat secara baik.

\section{Informan IV (Sugiyarto, 43th)}

Informan ini merupakan pendengar yang mengikuti siaran RRI Semarang, khususnya di frekuensi pro 2 FM yang bersegmen musik dan informasi. Ia mengikuti siaran RRI Semarang karena siaran musik dan informasi terus di sesuaikan dengan selera kalangan muda. Namun, memberikan warna baru akan lagu-lagu yang disajikan.

Pak Sugiyarto ini mengaku, radio RRI Semarang khususnya Pro 2 menemaninya saat menjalani tugas-tugasnya. Sebagai security dalam sebuah perusahaan swasta terkemuka di Semarang, radio menjadi bagian yang sangat vital karena bisa membantu mengusir rasa bosan dalam rutinitasnya sehari-hari. Kehadiran siaran RRI Semarang yang menyuguhkan lagu-lagu favorit mampu mengusir rasa gundah dan benar-benar menghibur. Lagu-lagu tersebut dimunculkan sangat variatif, sesuai dengan segmentasi waktu yang telah menjadi agenda rutin, seperti lagu-lagu dari grup musik Kotak band, Zigas band, Kangen band, Gigi band, Maha dewi, dan grup musik baru lainnya. Selain itu, juga ada segmen lagu-lagu campur sari, Ditambah lagi dengan suguhan informasi mulai dari even-even di Semarang, berita yang ringan hingga politik memberikan tambahan yang bermanfaat bagi masyarakat.

\section{Informan V (Yuni Ekowatini,40 th)}

Informan ini merupakan pendengar yang mengikuti siaran RRI Semarang. Ia sering kali mendengarkan RRI Semarang berkaitan dengan agenda kegiatan yang laksanakan dan juga komunitas lain yang bekerjasama dengan RRI Semarang.Informasi itu ia butuhkan untuk menggali informasi tersebut berkenaan dengan tugas-tugasnya sebagai tenaga administrasi di sebuah perusahaan penerbitan swasta. Ia juga mengamati berbagai iklan yang muncul di radio tersebut sehingga mampu memberi referensi pada bidang marketing untuk ditindaklanjuti sebagai bagian dari kegiatan komunikasinya.

Banyaknya informasi yang ia terima, memberikan inspirasi untuk terus menggali informasi se-dalam-dalamnya mengenai RRI Semarang. Munculnya informasi yang dikemas dengan pengumuman, iklan atau jenis lain yang disiarkan membuka peluang baginya untuk menjalin 
kerjasama dengan perusahaan atau lembaga yang terlibat dalam informasi tersebut. Ia mengaku, bahwa frekwensi iklan di RRI Semarang saat ini jauh lebih banyak dari pada waktu-waktu lalu. Banyak sekali iklan yang muncul, mulai dari iklan layanan masyarakat seperti iklan yang memberikan pendidikan dan pembelajaran pada masyarakat, seperti iklan pentingnya melakukan KB (Keluarga Berencana), bahaya Merokok dan lainnya. Iklan komersil seperti dari perusahaan,makanan, minuman dan perusahaan lainnya menghiasi iklan-iklan di RRI Semarang.

\section{Simpulan}

Dari hasil temuan di lapangan dapat disimpulkan sebagai berikut ;

1. RRI Semarang telah banyak melakukan banyak kreasi dalam menarik simpati pendengar, seperti selalu update terhadap acara musik maupun informasi dalam bentuk penyajian berita yang terbaru.

2. Kreatifitas diwujudkan dengan memperkuat program siaran di frekuensi Pro 1 hingga Pro4. Program dimaksud adalah program yang mampu melibatkan pada masyarakat secara langsung dalam bentuk interaktif dengan isu-isu menarik sesuai dengan masalah lokal Semarang, dan di Jawa Tengah

3. RRI Semarang mampu melestarikan aspek budaya lokal, dengan menyelenggarakan pertunjukan budaya yang menarik simpati dan membangkitkan rasa memiliki masyarakat Jawa Tengah seperti Gelar budaya Wayang Kulit, Gelar musik campur sari, keroncong, maupun musik modern yang notabene menjadi budaya lokal di Jawa Tengah.

4. Kurangnya publikasi dan informasi atas perubahan dan peningkatan yang terjadi di RRI khususnya di Semarang.

\section{Saran}

1. RRI Semarang diharapkan agar terus menggali potensi yang ada dengan mengoptimalisasikan sumber daya dan terus menunjukkan dengan kreatifitas.

2. Melakukan pendekatan dengan banyak komunitas dengan melakukan kegiatan bersamasama yang saling menguntungkan dengan frekuensi lebih banyak.

3. Melakukan penguatan program-program up to date yang dilandasi dengan IPTEK dan kemajuan teknologi informasi dan dilakukan sosialisasi serta publikasi pada masyarakat.

\section{DAFTAR PUSTAKA}

\section{Buku Cetak :}

Alma, Buchari. Manajemen Pemasaran dan Pemasaran Jasa. Bandung: Alfabeta.2009.

Sutopo, HB. Metodologi Penelitian Kualitatif. Surakarta: Sebelas Maret University Press.2010.

Pawito. Penelitian Komunikasi Kualitatif. Yogyakarta.Lkis Pelangi Aksara.2008

Sudarmawan,Wahyu. Pemasaran Program Siaran Radio \& TV.Jalasutra.2007.

Nawawi, H. Hadari., H.M. Martini Hadari. Instrument Penelitian Bidang Sosial. Yogyakarta: Gajah Mada University Press. 2010

\section{Jurnal Cetak :}

Rosalia,Naiza. Faktor-faktor Daya Tarik Stasiun Radio.Semarang: Undip.2008.(7-11)

Sugiyono. 2008. Metode Penelitian Kuantitatif Kualitatif dan $R \& D$. Bandung: Alfabeta. 


\section{Ucapan Terimakasih}

- Tim Jurnal Jurnal Ilmiah Komunikasi MAKNA yang telah memuat jurnal ini

- Universitas Dian Nuswantoro Semarang melalui LPPM yang telah membiayai penelitian ini.

- RRI Semarang sebagai tempat untuk meneliti

- Dan semua pihak yang telah membantu penelitian ini 